\title{
Commercial airline pilots' declining professional standing and increasing precarious employment
}

\author{
G.A. Maxwell - corresponding author \\ Reader (in HRM), Department of Business Management \\ Glasgow School for Business and Society \\ Glasgow Caledonian University, Cowcaddens Road, Glasgow G4 OBA, United Kingdom \\ T: +44 (0)1413313191E: g.maxwell@gcu.ac.uk
}

K. Grant - co-author

Lecturer (in HRM), The Business School

Edinburgh Napier University

Craiglockhart Campus, 219 Colinton Road, Edinburgh, EH14 1DJ, United Kingdom

T: +44 (0)131 4552367 E: k.grant@napier.ac.uk

\begin{abstract}
With the advent of low cost employment systems for pilots in commercial airlines, we address two questions: What are experienced UK-based, commercial airline pilots’ perspectives on their current professional standing? What are their perspectives on current precarious employment in commercial airline piloting? Analysis of qualitative data from 28 pilots in commercial, passenger carrying airlines reveals declining professional standing and increasing precarious employment, alongside enduring aspects of professionalism.
\end{abstract}

The corollary is that precarious professional employment is an emerging, pervasive type of low cost employment system in the studied context. In terms of theoretical implications, our study highlights the need for exactness in understanding the complexities of declining 
professional standing and increasingly precarious employment. Our analysis offers an exact term, pilot-cariat, to encapsulate contemporary, UK-based and experienced commercial airline pilot employment. Further research may reveal more of what we call cariats in other occupations with responsibility for lives in similarly cost constrained and management agency contexts.

\section{Key words}

commercial airline pilots

precarious professional employment

\section{Introduction}

Commercial aviation is facing a number of challenges including intense competition (RiwoAbudho, Njanja \& Ochueng, 2013). Although commercial air travel continues to expand globally, it typically yields less than 3 percent profit margins (Aviation Trends, 2015). The expansion of low cost passenger airlines especially has added pressure to levels of competition (Sarker, Hossan \& Saman, 2012) and customer service (Baker, 2013) in the longer established legacy airlines. Thus there is a narrowing of the difference between legacy and low cost airlines. The expansion of low cost carriers, in the UK and elsewhere, is affecting pilots' employment in commercial, passenger airlines in that it is increasingly likely to centre on low cost employment systems throughout the commercial airline industry, sometimes referred to as the Ryanair effect (Harvey \& Turnbull, 2010; Oxenbridge, Wallace, White, Tiernan \& Lansbury, 2010). Additionally, ‘in recent years there have been profound changes in the operating environment and management practices of airlines' (Bamber, Hoffner Gitell, Kochan \& van Nordenflycht, 2015, p636), with 'structural changes sweeping through aviation industry’ (Fraher \& Gabriel, 2014, p.947). Consequently, commercial airline pilots' employment in many countries, including the UK (The Guild of Air Pilots and Air Navigators of London, 2004), is no longer a secure, highly paid profession as a whole. 
The changing nature of pilots' employment in commercial airlines has been investigated in US studies (Fraher, 2014 \& 2016; Fraher \& Gabriel, 2014 \& 2016). It has also been studied, over 10 years ago, in the European low cost sector (Pate \& Beaumont, 2006) and in the UK low cost sector (Bennett, 2006). More recently, there have been studies on pilots in Australian and Irish owned legacy airlines (Oxenbridge \& Wallace, 2010) and in 'liberalmarket economies and coordinated-market economies’ including Britain (Bamber et al., 2015, p.635.) However, relatively few studies, except and since that of Harvey and Turnbull's (2010) original work, have concentrated exclusively on commercial pilots’ employment in the UK context, hence this article is timely. Underlining the timeliness of the article is the very recent implementation of the European Aviation Safety Agency’s (EASA) policy on flight time limitations in the UK (Civil Aviation Authority, 2015). The policy harmonises flight time limitations across Europe. It reduces pilots’ flying time in many European countries yet raises the upper limit of flying times for UK-based pilots, constituting a key change in their employment.The increase in the UK from 900 to 1,000 flying hours p.a. may be perceived by pilots to detract from their employment experience. Webb (2004, p.719) made the point that individuals' experiences of work are foregrounded in 'advanced capitalist societies characterised by deregulation' - such as the UK-based commercial airline sector.

The aim of the article is therefore to address the questions of: What are experienced UKbased, commercial airline pilots' perspectives on their current professional standing? What are their perspectives on current precarious employment in commercial airline piloting? To set the scene, we first discuss contemporary issues in commercial pilots' employment. We then discuss professional standing and precarious employment in turn, theorising that professional and precarious aspects of employment are not mutually exclusive. The nature of professions can change and studies have shown that both the context and nature of professional work has ‘changed drastically in recent years’ (Johnston, Maggiori \& Rossier, 
2016, p.81). At the same time, academic interest in precarious work has increased recently and there have been calls for further research on this type of employment (Benach, Vives, Tarafa, Delclos \& Muntaner, 2016) with its distinct echoes of labour process theory (Thompson \& McHugh, 2002). Further, Bennett (2006, p.112) called for more studies into aircrew to 'broaden and deepen our understanding of one the industry's most vital resources'. On this basis, the research design, empirical findings, discussion and conclusions follow.

\section{Contemporary issues in pilots' employment in commercial airlines}

According to Bennett (2006), there are two contrasting sides to commercial airline pilots’ employment. On one side, 'aviation can be seen as a glamorous, enjoyable pastime' (Bennett, 2006, p.93), possibly reflecting a superficial and external sightline. Conversely, Bennet (2006, p.93) continued that aviation can be seen as 'a poorly rewarded and risky battle with fatigue, stress and exploitative terms and conditions,' likely reflecting a closer insight into

pilots’ employment experiences. Bennett's (2006, p.110) longitudinal ethnographic study of captains and first officers in a UK low cost airline revealed 'an unglamourous world of fatiguing rosters, delays, disruptions, convoluted positioning and difficult passengers.' Furthermore, commercial piloting is subject to downsizing, restructuring and job insecurity (Bajawa \& Woodall, 2006; Fraher \& Gabriel, 2016; Gittell, Cameron, Sandy, \& Victor 2006), as well as the impacts of the September 112001 terrorist plane crashes in New York (Fraher, 2016) and the 2008 global financial crisis (Edemariam, 2015).

In addition, working as a commercial airline pilot has been linked to occupational health concerns, for example emotional stress due to job responsibility (Butcher, 2003), and the negative effects of shift working patterns (Jackson \& Earl, 2006). Moreover, a number of aviation agencies signal pressing contemporary issues in commercial pilots’ employment. For example, pilot fatigue has long been recognised by the National Transportation Safety Board 
(NTSB) in the US (e.g. Rosekind, 2010) and by the Airline Pilots’ Association (2008) in Canada as a safety and employment issue. It is also is recognised as an issue by the UK's Civil Aviation Authority (CAA, 2007) and by the European Aviation Safety Agency (www.easa.org). Another example of a contemporary issue in commercial pilots’ employment is the EASA (2017) new guide on safety management due to the effects of low cost business system and atypical employment patterns. The European Cockpit Association (2017) is currently campaigning for the end of pay-to-fly training whereby licensed pilots gain their required type-rating for flying not by earning a salary but by paying an airline to fly as a qualified crewmember. Such an atypical employment system is an inversion of paid employment to paying for employment that is not only a very poor reward but also overtly exploitative.

The principal association for airline pilots in the UK is the British Airline Pilots' Association (BALPA). It acts for its 10,000 plus members as the dominant professional association and registered trade union for more than 75 percent of all fixed wing and helicopter aircrew pilots working in the UK (www.balpa.org). Included in the current campaigns BALPA is representing its members on are casualisation and the use of contract labour, and pilot fatigue which has been stepped up as a campaign due to the aforementioned recent increase in permitted flying hours (www.balpa.org/Campaigns). The former campaign relates mainly to the low cost, passenger sector of the industry, and BALPA links the high cost of gaining a commercial pilot's license, around $£ 120,000$, to this issue (www.balpa.org/Campaigns). It is commonplace for pilots to self-fund their commercial license, possibly in recognition of potentially earning, in time, $£ 95 \mathrm{k}+$ p.a. and a median gross salary of $£ 84,453$ (Ferguson, 2013). According to the 2013 Office of National Statistics' (ONS) Annual Survey of Hours and Earnings, these figures make piloting one of the highest paid jobs in the UK. However, salaries in low-cost carriers are notably less than these figures, especially for new pilot 
recruits who can join with debts in the region of $£ 100,000$ for gaining the necessary flying license, leaving them with around $£ 500$ per month to live on (Tovey, 2014). Indeed some newly licensed pilots may even have to pay to fly rather than be paid to fly as noted above. At the present time, BALPA is representing pilots working for British owned holiday company Thomas Cook who are striking, the first pilot strike since the 1970s (BBC News, www.bbc.co.uk). Notably, pay and employment practices for pilots working for the Irishowned low cost, passenger airline Ryanair have been criticised (Wright, 2013). In particular, Ryanair’s contracting out pilots’ employment and having 70 percent of its pilots on zero hours contracts, paid only for their flying time, has been heavily criticised (Cahill, 2015). The current controversy over Ryanair's multiple flight cancellations (www.bbc.co.uk/news) and crisis in churn among pilots due to their employment conditions (Atkinson, 2017) is very likely to add to the criticism. Further, Ryanair pilots are reported to be acting collectively to improve what they perceive as poor employment conditions and management disregard of their professional standing (Davies, 2017). With a major operating base in a London airport, this airline's employment system has heavily influenced the emergence of the low cost employment models permeating UK aviation as a whole (Jorens, Gillis, Valke \& De Corninck, 2015). These contemporary piloting issues bring us to consideration of professional standing and precarious employment in turn.

\section{Professional standing}

Haug's (1975) influential and somewhat controversial discourse on deprofessionalisation sought to argue that the external standing of professions would decline and level out to be the same as non-professional occupations in the $21^{\text {st }}$ century. Indeed, it projected and partially predicted a deprofessionalised future for professions founded on status, autonomy and authority as 'knowledge monopoly and decline of public belief in professional goodwill' (Haug, 1975, p207). Deprofessionalisation and hence professional standing is arguably 
founded on the 'phenomenon' of professionalism (Friedson, 1994, p.7). As a dynamic entity (Brock \& Saks, 2016), professionalism is a topic of enduring debate, some of it heated (Bourgeault, Benoit \& Hirschkorn, 2009) and much of it disputed (Brock \& Saks, 2016). An integral part of the debate on professionalism is the very meaning of the term, which is a ‘contentious issue' across a number of academic disciplines including sociology and management according to Brock (2006, p.3). Brock (2006, p.3) has posited that professionalism centres on proficiency, which includes 'behaving' elements of positive, demonstrable behaviours such as commitment. Evans (2008) made the point that professionalism relates to status elements of work while professionality relates to the knowledge, skills and processes inherent in work. Professionalism can therefore be viewed as a capability and professionality as a means of enacting that capability. Further, for Bourgeault et al. (2009) and Evetts (2011), professionalism can be a management tool in that it is used by employers and managers to leverage change and control, calling up labour process theory (Taylor \& Moore, 2015; Thompson \& McHugh, 2002). For Friedson (2001), increasing managerialism and cost-consciousness is pervading professions, such as medicine, so dealing with competing logics has become necessary. Johnston et al. (2016, p.81) have highlighted that the contemporary 'professional world' involves complexity and uncertainty. Similarly, Evetts (2011, p.406) has asserted that 'professionalism is changing' and Muzio, Brock \& Suddaby (2013, p.699) that professionalism can be 'reconceptualised'.

While definitions and dimensions of professionalism appear debatable, contemporarily it is arguably a phenomenon encapsulating proficiency and exemplary behaviour that is bound by management agency. By extension, professionals can be conceived as people in a role which, elementally, requires a high degree of competency, high standards of personal conduct and responsibility, yet are subject to external (management) control. Professionals are still needed according to Friedson (2001). Despite prediction of the disappearance of professions (Haug, 
1975), the term professional has not only endured but expanded in usage (Adams, 2014) and in insight (Worrall, Mather \& Cooper, 2016). Rather than the concept of profession becoming ‘obsolete’ (Haug, 1975, p.211), aspects of it are still manifest in descriptions of pilots.

Patton (2015, p.9) referred to the 'professionalism of commercial airline pilots' in his advocacy on pilots' health self-reporting following the fatal Germanwings airplane crash in 2015. Pilots have been described as a 'group of privileged professionals' (Fraher \& Gabriel, 2014, p.927) in the context of a study of the occupational identities of US pilots, although these authors concluded that the profession is 'currently under-going extensive downgrading' (p.947). Ashcraft (2007, p.9) found men pilots in the US saw themselves as being 'elite, fatherly professionals’ while in a UK-based study, Bennett (2006) found evidence of professionalism among aircrew. Thus, being professional and having professionalism appear to suffuse pilots’ employment. Harvey and Turnbull (2010, p.233), however, have asserted that 'status is of paramount importance' to pilots yet can diminish readily 'by lower pay and reduced benefits, as well as by the very concept of "low cost airline”.' The inference they drew is that 'pilots are no longer high status professionals' (Harvey \& Turnbull, 2010, p.233). Status can be externally perceived (Haug, 1975) or internally perceived by individuals (Bevort \& Suddaby, 2015).

In the face of the issues in commercial pilots' employment as above, it can be levelled that the professional standing of commercial airline pilots is declining, underscoring that professionalism is a dynamic entity (Brock \& Saks, 2016). Focusing on the internal perceptions of individual pilots, and not deprofessionalisation per se, this gives rise to the question of what are experienced UK-based, commercial airline pilots' perspectives on their current professional standing? It also brings us to consideration of precarious employment as an expanding type of employment, which may now have some connection with pilots' employment. 


\section{Precarious employment}

Precarious employment is a contemporary typology of employment associated with globalisation (Burgess, Connell \& Winterton, 2013). A number of studies have documented the global expansion of precarious employment, for example in Europe (Kretsos \& Livanos, 2016) and in South Africa, Mexico, the United States, China and India (Mosoetsa, Stillerman \& Tilly, 2016). European writers attribute the growth of precarious employment to the processes of neoliberal globalisation which are stimulated by privatisation, a drive for increased profits and reduced costs, and the erosion of social welfare (Hewison, 2016).

Whilst one of the earliest analytical applications of the term precarious work was used by Rodgers and Rodgers (1989), more recently the term gained academic and political traction through the work of Standing (2011). Yet precarious employment has been criticised in lacking conceptual clarity (Mosoetsa et al., 2016) and, consequently, consensus in definition. For instance, Prosser (2015, p.2) proffered that: 'precarious work is defined as employment involving contractual insecurity; weakened employment security for permanent workers and non-standard contractual forms such as temporary agency, fixed term, zero hours and undeclared work.' According to Benach \& Muntaner (2007, p.276), precarious work is 'characterised by variable work schedules, reduced job security, lower wages, hazards at the workplace and stressful psychological working conditions’. These definitions chime with Burgess et al.’s (2013) discussion on the nature of precarious work, though they factor in poor physical working conditions and negative work-life balance too. Informed by such definitions, precarious employment is defined theoretically in this article as exacting, insecure and unsafe aspects of employment bound by management agency. Kalleberg (2012) has called for more insight into the nature, so meaning, of precarious work. Significantly, precarious employment has been framed as ‘a core concern in modern societies' (Vono de Vilhena et al., 2016, p.91). Anderson (2010) pointed out that it is a current feature of work in 
the UK, while Standing (2011, p.3) has taken a global perspective of what he called the 'precariat' which excludes professional employment in his exposition.

Many of the characteristics of precarious employment identified above connect directly to working as a commercial pilot as set out earlier, especially, but not exclusively, in the low cost sector. These include: contractual insecurity (Bajawa \& Woodall, 2006; Cahill, 2015; Gittell et al., 2006); emotional stress (Bennett, 2006; Butcher, 2003); fatigue due to shift working patterns (Bennett, 2006; Jackson \& Earl, 2006); and debts incurred in qualifying as a pilot (ECA, 2017; Tovey, 2014). Additionally, precarious work has been strongly linked to poor occupational health (Benach \& Muntaner, 2007; Hopkins, 2015; Lewchuk, Clarke \& de Wolff, 2008). Commercial airline piloting too has been linked to occupational health concerns, for example the negative effects of fatigue and sleep loss (ALPA, 2008; BALPA, 2017; CAA, 2007; Jackson \& Earl, 2006; Rosekind, 2010).

Vono de Vilhena et al. (2015) have cited the work of Kalleberg (2012) as evidence that precarious work is not confined to low skill occupation. Rather, it is expanding 'among all occupational levels, including the traditionally protected, skilled and often highly unionised workforces of large firms' (Vono de Vilhena et al., 2015, p.2). Furthermore, having a high level of knowledge does not necessarily preclude employees from precarious work nor does it necessarily include employees in non-precarious, secure and well-rewarded work (Vono de Vilhena et al., 2015, p.2). Putnam, Myers \& Gaillard's (2014, p.1) critique of flexible employment identified tensions between 'variable and fixed working arrangements, supportive and unsupportive work climates, and equitable and inequitable implementation of policies’ which connote with precarious employment particularly.

Significantly, precarious employment and professional employment are mainly considered in mutually exclusive terms in extant literature, notably in Goos, Manning \& Salamon’s (2009) 
polarisation. A somewhat conspicuous exception to this is Thomson and Jones' (2016, p1) study on what they coined 'precarious professionals', namely accountants migrating to Canada. These researchers found that migrant accountants were not recognised or included by their Canadian colleagues as professionals, leading to professional insecurity among the studied group (Thomson \& Jones, 2016), resonating with a decline in professional standing. While the work of these authors does not consider the precarious employment literature, it nevertheless conjoins professional employment with precarious employment, opening up the possibility that these two types of employment can co-exist. Implicit in Fraher’s (2016, p.6) proposition of American pilots as ‘quasi-professional experts' is an element of precarious employment too, in terms of employment vulnerability:

their expert knowledge and unique employment vulnerability....as employees who have a unique skill developed through talent and experience which allows them to work autonomously within an organisational structure, and for that they are trusted and well compensated.

Thus it can be levelled that commercial airline pilots’ employment is moving more towards increasing precariousness as its professional standing is declining, giving rise to the research question of what are the perspectives of experienced UK-based pilots on current precarious employment in commercial airline piloting? With two research questions now posed, the empirical research design is discussed next.

\section{Research design}

The inductive research approach to the empirical study constitutes a generic qualitative study to expand insights (Gioia, Corley \& Hamilton, 2012) into the current nature of professional standing and precarious employment for experienced UK-based pilots in commercial, passenger carrying airlines. The empirical data collection comprised in-depth semi-structured 
interviews with experienced commercial pilots working for UK-based passenger carrying airlines, flying in and from the UK, to address the two research questions in this specific part of the global aviation industry. The advantage of interviewing was considered to be obtaining deep, rich accounts of personal opinions and feelings on their employment, based on individuals’ piloting experiences of at least two years.

A snowballing technique of pilot interviewee referrals was utilised. From two opportunistic initial interview contacts, each pilot interviewee was asked for several referrals of other potential pilot interviewees. Potential participants were contacted by the authors and included as interviewees on the basis of their willingness and availability. Relying on one method of data collection is acknowledged as a research limitation, hence a review of BALPA reports on pilots' attitudes to their jobs complemented the interviews.

Open questions on six topics relative to personal views on and experiences of employment were posed to each informant pilot, in a semi-structured format. The topics were: background to becoming a pilot; employment expectations and contract; role and responsibilities; reward and recognition; work organisation and employer support; security and critical incidents. Including piloting of the questions, 28 pilots were interviewed, from July 2015 to September 2016, by which time it was considered saturation point in the findings was reached (Charmaz, 2006). Underlining the sufficiency of the number of interviewees, Patton (2015) contended that the quality of insights is more important than the number of research informants. This position is substantiated by Gioia et al. (2012, p.24) who emphasise that a small sample is possible where it 'generates concepts or principles with obvious relevance to some other domain.'

Between them, the 28 interviewees had flown with seven well known, currently operating commercial airlines in the UK. Twenty five had commercial experience across legacy and 
low cost airlines, four of low cost airlines only. Seventeen interviewees were captains and 11 were first officers, ranging in experience from 8 to 43 years, across an age span of late 20s to early 60s. The interviewees had at least 6,500 hours commercial flying time each and 26 were men, two were women. Only three were former Royal Airforce (RAF) pilots, reflecting the diminution of the RAF as a source of recruitment of commercial pilots in the UK (Edemariam, 2015). The characteristics of the interviewees were not pre-selection criteria; rather, the only criterion was that the pilots had to have at least two years of flying experience as captains or first officers to afford depth of insight.

Each interview usually lasted around one and half hours, while a few lasted over two hours. Each interview was recorded and subsequently transcribed, with some data editing of extraneous comments. This technique allows an initial reduction of the data to 'manageable proportions' (Anderson 2004; p.169). During the period of interview data collection, the researchers frequently discussed with each other the findings in the interviewees’ own words, a form of first order analysis (Gioia et al., 2012). Thereafter, from a final data tranche of 55,000 words, the main aspects in the findings were again discussed and distilled in a process analogous to Gioia et al.’s (2012) second order analysis. The authors engaged in close, repeated reading of the transcripts to appreciate meaning and inherent themes, then coded the emergent themes to gather the data in each theme for closer scrutiny (Creswell, 2014). The principal emergent themes ('aggregate dimensions’ in Gioia, Corley \& Hamilton’s (2012, p.20) terms) were: declining professional standing; increasing precarious aspects of employment; and enduring professional aspects of employment. Peer review of the data coding corroborated these themes.

To illustrate the main findings in each emergent theme, quotations from individual captains and first officers are framed anonymously though coded and numbered as captains (C1-17) 
and first officers (FO1-11). The interviewees agreed with this presentation and it serves to indicate the spread of quoted sources in a systematic, anonymous way.

\section{Findings}

\section{Declining professional standing}

All of the interviewed pilots considered that contemporary employment changes in UK-based commercial, passenger aviation are substantial and that they are permeating the industry in its entirety. Some recent changes may be more marked in some low cost airlines, but they are nonetheless 'evident in even the best and high reputation legacy airline,' in the words of one interviewee (C5) who said he was voicing this view on behalf of all of his pilot colleagues in several airlines. Conspicuously, all of the interviewed pilots acknowledged the changing nature of pilot employment in negative terms. A captain (C6) exemplified this: 'People in the industry are depressed the way it's gone - you work a lot harder and the salaries, except for the major carriers, are not what they used to be. The Ryanair system has set the tone and filtered down. It doesn't bode well.’ Picking up on the sense of foreboding, others noted: 'It's getting worse, more and more things are added onto your job' (C14); and 'The golden period of flying was probably about 10 years before I joined, when the captain and crew and treated well by all the airlines. I think everyone from that period went into flying with the expectation that they were going to have a fair degree of authority and autonomy and respect, but I don't think that's the case now. Over the years airlines have been treating their staff increasingly as a number, a commodity’ (C13). Other pilots’ remarks emphasised that airline employers are devaluing their pilots:

'I’m not convinced that my particular employer is very pro-pilot. I think we're considered expensive necessities, luxury items they would rather have done away with, but if you want to have an airline that operates aeroplanes, at some point you need to have pilots' (C11); and 
'I'm just a number that sits in the seat and flies the roster, we're [commercial airline pilots] just not valued by people at managerial level. We're just a necessary expense' (FO10).

Nonetheless, there was a very widespread perception that: 'Aviation is still professional' (C6); and that: 'We [pilots] are professional, though it's being eroded on a regular basis' (C4).Whilst the pilots consider themselves as professionals, it was found, overall, that their employment experiences of recent and on-going changes constitute a decline in their professional standing and a move towards precarious aspects of employment.

\section{Precarious Aspects of Employment}

A first officer encapsulated negative aspects of pilots' employment thus: 'There is a massive topic about what pilots put up with. It's so destructive. An airline CEO is up for a business leader of the year award - it should be exploiter of the year' (FO2). The pilot interviewees cited several factors within their employment which may be regarded as precarious. These principally centre on substantial personal debts incurred to train as a pilot, aggressive cost cutting practices undertaken by airlines, and increased fatigue due to recently increased flying time.

Personal costs and debts are often incurred in becoming a commercial pilot in the UK, as reported by many of the pilots. Even when employed, additional self-funded type-rating training in the region of $>£ 25,000$ may be required by the employing airline to train on particular aircraft, as explained by several interviewees. Many pilots emphasised this point strongly, using adjectives like 'outrageous'. Further, it was recounted that: 'Pilots struggle to pay their debts - to the tune of $£ 120,000$ with a starting salary of $£ 20,000$ ’ (C7). This can bring substantial pressure: 'Some first officers are under huge pressure to fly, especially if they're on contracts where they are being paid by the hour...they’ve still got to pay back their loan and rent' (C11). A first officer expanded on the pressure: 'You pay around $£ 100,000$ or 
more to do a proper course at a flying school but the airlines then have the upper hand because they say “if you want a job with us you'll pay whatever we ask, you'll do whatever we tell you and you'll go wherever we want.” How they survive and get food and accommodation close enough to the airport I don't know. I think it puts an awful lot of psychological pressure on these people just to survive and turn up to work every day' (FO8).

In addition it is a widespread opinion that intensified growth and competition between airlines has resulted in continued, aggressive cost cutting strategies in order to remain competitive. 'It's all driven by continued cost cutting right across the industry, and that is the principal fault in many of the current issues' (FO6), in the words of one pilot. Nearly all pilots spoke emphatically, sometimes emotionally, about the growing distance between operational/ commercial managers and flight crew. Captains and first officers see a divided industry. To illustrate, it was explained that: 'We all have different agendas, it's odd, there’s no reciprocity. I believe if you treat people well, you'll get more back from them, but aviation tends not operate like that now' (FO2).

Cost saving practices were also reported as resulting in mounting tension between the commercial and safety aspects of aviation. It was emphasised by two interviewees that: 'Pilots perform a safety role and the business performs a profit role, and the two don't necessarily match up’ (FO9); ‘There’s no thought about what's the right or wrong way, or even the best way, it’s more and more just the minimum way' (FO4). Consequently, commercial costs pressures were perceived to be prioritised by airlines above safety. In short, 'It seems that doing things within a safety environment is not nearly as important as doing things within a cost effective environment. That, I think, is the paramount factor for modern airline living, sadly’ (C13). 
Highlighting the employment impact of cost cutting commercial decisions in closure of bases, it was explained that: 'When on standby you have to be within an hour of the airport, and when you live three hours away you spend a lot of time hanging around car parks...I never envisaged myself having to do that' (C10); 'It's almost impossible to hold down employment with an airline because they are moving bases so frequently' (FO7). Thus it can be seen that commercial decisions can inconvenience the pilots and undermine their job security.

Indeed job insecurity arose as a key concern. All captains and most first officers referred to insecure employment contracts, for example: 'New pilots are employed as contractors which has massive implications. Employers can get rid of you, there's no guarantee of a longterm career with a company' (C8). In the same vein, most first officers spoke of contractual change, as one (FO2) indicated: 'A 100 percent job offer can be changed to a 75 percent contract. I know pilots who take extra jobs as in some airlines the pay is derisory. I worry that they are starting to chip away at our terms and conditions - in other airlines they take a pneumatic drill to them!'

One of the greatest concerns, raised by all of the interviewees, was the 2016 change to flight time regulations increasing the upper limit of flying time. While these flight time regulations provide a maximum limit, most of the pilots stressed that many airlines now treat this as an operating norm. C4 reckoned that 'They [managers] take a cold hearted, statistical point of view of what they think is realistic for you to work to the maximum. They think you're a machine, and say work hard, then go home to bed, not actually saying they know you are worn out. I'm always wrecked.' C12 asserted that 'For maximum efficiency they need all of us to almost fly up to our limits in order to get the most value for money.' Resultantly, 'More and more pilots are going part time because of fatigue and higher tax levels, a win-win as the company keeps productivity and saves on the salaries of more experienced and expensive 
staff'(FO2). Requests for contractual change by reducing working hours to part-time working is becoming increasingly being common. 'I've applied for part-time, 70 percent work and been told that I'm $26^{\text {th }}$ in line for this! So many pilots are requesting part-time now' (C6) as an example.

All of the pilots spoke in their own way of potentially serious and unsafe consequences, such as flawed decision-making, resulting from extra tiredness due to the implementation of the rise in flying hours. Underlining the fatigue factor in pilots' employment, a first officer explained 'When you're fatigued your world changes. It happens to everybody and I worry that it is making flying less safe' (FO7). Overall, it is therefore apparent that the precarity of the pilots' employment amount to increasingly exacting, insecure and unsafe aspects framed by management agency.

\section{Professional aspects of employment}

The key emergent aspects of the pilots’ professional employment centred on accepting personal responsibility for lives, in-flight decision-making, and continual scrutiny. In terms of personal responsibility for lives, it was asserted, for example, 'If you’ve got a 78 seater plane, you're responsible for 78 passenger lives' (C6). Concurring, another interviewee stated: 'There are very few professions where you have responsibility for lives, multiple times a day' (C4).

Others recounted their main responsibilities in terms of professional aspects of employment: 'You have to maintain standards and ensure professionalism always with the people working with you, acting professionally with customers and colleagues' (C1); 'It's [working as a pilot] being professional and being seen as being in a professional career from the public's point of view in order for them to feel safe to travel' (C2), for example. Similarly FO2 noted: 'You have to come across as fitting a professional role and character.' Therefore, the very high 
level of responsibility coupled with embodying professionalism is recognised among the pilot interviewees.

Whilst Standard Operating Procedures govern most in-flight decisions, the pilots spoke of the wholly autonomous and critical decision-making aspects of their particular role in emergency and critical situations. This point was illustrated by a captain (C4) who commented: 'We can have hours and hours of boredom punctuated by times of sheer terror...quick decision reaction time is three seconds, one second if you're near the ground.' Similarly, a first officer (FO11) stated: 'That [inflight decision-making] brings us back to professionalism in terms of being able to handle [critical] types of incidents.'

Each interviewee explained that maintaining a commercial license involves continuous training, assessment, and demonstration of adherence to the high standards demanded by the UK's Civil Aviation Authority (CAA) and individual airlines in order to be able to manage all incidents. All of the pilots also raised the necessity of the scrutiny of their work, while many referred to a management view of the pilots as operational objects. As one (FO2) succinctly put it: 'It's all recorded, voice and data recorded etc, so they assume total pilot compliance.' Expanding on management's treatment of their pilots, another for example asserted that 'They [management] are very quick to accuse people in a biased way, they make an assumption and try to prove it, the opposite of what it should be. There is a 'just culture' phrase in the industry at the moment, driven by the CAA regulator which makes it even worse. It sounds like 'just desserts' more than a fairness culture!'(C9). Again, implicitly, the co-existence of precarious and professional aspects of employment is clearly apparent.

\section{Discussion}

Addressing the research question on experienced UK-based, commercial airline pilots' perspectives on their current professional standing, the collective and cogent perceptions of 
the interviewees' evidence that the UK-based pilots are experiencing a deterioration in their employment. This deterioration pervades commercial airlines although it is presently more pronounced in low cost passenger carriers. It was generally attributed to the pressures of competition in a cost driven industry driving cost reducing employment strategies (Sarker et al., 2012) and concomitant extension of what Harvey and Turnbull (2010, p.230) called a 'low cost employment system’. Hence, the Ryanair effect (Oxenbridge et al., 2010) seems to be reaching out ever further across commercial aviation. Most specifically, the deterioration in pilots' employment conditions and experiences was attributed to the very recent increase in permitted flying hours which UK airlines were reported to be applying as an employment norm, not an upper limit. The findings from this study support Haug's (1975) thesis on deprofessionalism in professional standing to the extent that the UK pilot interviewees' perception is that their professional standing is declining in terms of their contemporary employment experiences, reflecting the 'extensive downgrading' of pilots in US aviation (Fraher \& Gabriel, 2014, p.947). Further, the decline is opined to be systemic and on-going, thus slipping incrementally more towards precarious employment. Consequently and implicitly, the pilots' collective perspective is that their employment is inclining more to precarious employment as a norm.

Addressing the research question on the perceptions of experienced UK-based, commercial airline pilots on current precarious employment, the interview data similarly reveals deterioration in their employment. Systemic cost cutting practices are manifest in substantial personal debts for pilot training, insecure employment contracts and in commercial airline pilots being treated as a cost, with work intensification due to increased flying times. These precarious aspects of employment echo the current typology of precarious work (Benach \& Muntaner, 2007; Prosser, 2015) and Bennet’s (2006) findings. It signals pilots increasingly 
being seen by their employers as quantified and objectified units of labour (Fuchs, 2014) and the growth of unsupportive work climates (Putnam et al., 2014).

It can be seen therefore that this study has highlighted a paradox of consequence arising from precarious employment practices. On the one hand, the costs of pilots to airlines has in effect been cheapened and the flexibility in their working hours increased. On the other hand, these financial benefits impact negatively on espoused human resource management goals such as trust and commitment (Burgess et al., 2013), with the studied pilots experiencing more precarious employment. Further, precarious employment produces the negative consequence of raised levels of individual pilot fatigue which has resulted in growing numbers of the more experienced, less indebted pilots requesting part-time employment. Furthermore, while airlines need to remain competitive, the competing interest of management for profitability and pilots for safety was regarded as a growing source of conflict. Thus cost saving measures have generated unintended and deleterious consequences. In particular, the indebtedness of newly qualified pilots has the effect of eroding and corroding pilots' perceptions of their employer. The lived experiences of the interviewed pilots affirms that neoliberal policies have provided a means for airlines to disengage from expensive training.

Consequently, the empirical evidence attests that precarious employment has expanded to include commercial airline pilots. For participants in this study reported uncertain, insecure and unsafe aspects of employment, bound by management agency. Yet, interestingly, at the same time, most pilots emphatically stated that pilots are professionals, indicating the somewhat oxymoronic co-existence of professional and precarious aspects of their employment. Nearly all participants spoke of their professionalism in terms of responsibility for passenger safety and in-flight decision-making responsibility, together with acceptance of continual scrutiny, albeit within a judgemental, even accusatory, culture. Overall the pilots’ evidence underlines and extends the contemporary definitions of professionalism and 
professionals proposed earlier in the article. That is, for the interviewed pilots, professionalism encapsulates proficiency and exemplary behaviour that is bound by management agency. Commercial airline pilots, as professionals, have a high degree of responsibility and competency, alongside in-flight autonomy for some decisions, yet are subject to regulatory control and increasing management scrutiny. However, the studied pilots are not ‘quasi-professional experts’ by Fraher’s (2016, p.6) definition as they do not consider themselves to be fully trusted by their managers or well compensated. Importantly, the findings illustrate a fusion of precarious and professional aspects of employment, rather than the two being mutually exclusive (Goos et al., 2009). Moreover, they illustrate the conjoined effects of declining professional standing and increasing precarious employment for UK-based commercial airline pilots in the contemporary context of management agency and organisational cost-consciousness in response to contentious changes in the regulations on flying hours.

\section{Conclusions}

Theoretically, our paper has three principal dimensions, in conclusion. Firstly, aligned to Muzio et al.’s (2013, p.699) view that professionalism can be 'reconceptualised,' contemporarily professionalism arguably encapsulates proficiency and exemplary behaviour that is bound by management agency. Secondly, we have argued that not only is professionalism mutating, but also professional standing is declining, partly supporting Haug’s (1975) thesis. Thirdly, we have argued that the decline in standing is associated with precarious employment which, though challenging to define (Mosoetsa et al., 2016), constitutes exacting, insecure and unsafe aspects of employment bound by management agency. Our empirical study provides evidence to substantiate, firstly, our theoretical definitions of professionalism and precarious employment, which have management agency in common. Secondly, the findings substantiate that professional standing is declining and 
precarious work is expanding in cost driven commercial airlines, according to experienced UK-based pilots themselves. Therefore, the findings signal the emergence of pilots now being precarious professionals in line with Thomson \& Jones' (2016) term. The corollary is that precarious professional employment is an emerging and pervasive type of low cost employment system in the studied context.

In terms of theoretical implications, it is noteworthy that our study highlights the need for exactness in understanding the complexities of declining professional standing and increasingly precarious employment. To be exact, our analysis exposes the emergence of what we call here the new pilot-cariat as a term that captures contemporary commercial airline pilot employment based in the UK. The pilot-cariat means being bound by management agency in maintaining proficient and exemplary behaviour in accepting responsibility for lives, while increasingly experiencing exacting, insecure and unsafe aspects of employment. Hence the research offers a contextual, contemporary insight into declining professional standing in better understanding of the nature and effects of precarious professional employment for UK-based commercial airline pilots in what we have dubbed the pilot-cariat. This new cariat, as we newly coin the term, may not only exist in the specific context studied in this article but also have relevance to other 'domains' (Gioia et al., 2012, p.24) such as similarly cost-driven occupations (Patton, 2015). Medical professionals working in similar UK contexts of increasing managerialism and cost-consciousness (Friedson, 2001) and responsibility for lives may be a notable example of another cariat worthy of empirical research.

Longitudinal research with UK-based pilots in all commercial airlines into the emergence of precarious professional employment generally, and the pilot-cariat specifically, would further inform insights into reconceptualised professionalism and newly conceptualised cariats. 
Research into contemporary pilot employment among experienced and new recruit commercial pilots who are employed by UK-based airlines but based in various European Union countries is another potential route for further pilot research.

\section{Acknowledgement}




\section{References}

Airline Pilots’ Association (2008). Fatigue Risk Management Systems: Addressing Fatigue Within a Just Safety Culture. ALPA White Paper. Retrieved from www.alpa.org Anderson, V. (2004). Research Methods in Human Resource Management, London: CIPD. Anderson, B. (2010). Migration, immigration controls and the fashioning of precarious workers. Work, Employment and Society, 24(2), 300-317.

Ashcraft, K.L. (2007). Appreciating the ‘work’ of discourse: occupational identity and difference as organising mechanisms in the case of commercial airline pilots. Discourse and Communication, 1(1), 9-36.

Atkinson, J. (2017). Unless Ryanair treats pilots like me better, this crisis will be long haul. The Guardian, 3.

Aviation Trends (2015). Strategy and PWC. Retrieved from www.strategyand.pwc.com/perspectives/2015-aviation-trends.

Baker, D.M.A. (2013). Service Quality and Customer Satisfaction in the Airline Industry: A Comparison between Legacy Airlines and Low-Cost Airlines. American Journal of Tourism Research, 2(1), 67-77.

Bamber, G.J., Hoffer Gittell, J., Kochan T.A. \& von Nordenflycht, A. (2015). Contrasting Management and Employment-Relations Strategies in European Airlines. Journal of Industrial Relations, 51(5), 635-652.

Bajawa, A. \& Woodall, J. (2006). Equal opportunity and diversity management meet downsizing: A case study in the UK airline industry. Employee Relations, 28(1/2), 4661.

BALPA (2017). Retrieved from www.balpa.org.

BBC News (2017). Thomas Cook pilots plan more strikes. Retrieved from www.bbc.co.uk. 
BBC News (2017). Ryanair publishes full list of cancellations. www.bbc.co.uk. Retrieved 22/9/17

Benach, J. \& Muntaner, C. (2007). Precarious employment and health: Research agenda. Journal of Epidemiology and Community Health, 61, 276-277.

Benach, J., Vives, A., Tarafa, G., Delclos, C. \& Muntaner, C. (2016). What should we know about precarious employment and health for 2015? Framing the agenda for the next decade of research. International Journal of Epidemiology, 61(4), 276-277.

Bennet, S.A. (2006). A Longitudinal Ethnographic Study of Aircrews’ Lived Experience of Flying Operations at a Low-cost Airline. Risk Management, 8, 92-117.

Bevort, F. \& Suddaby, R. (2015). Scripting professional identities: how individuals make sense of contradictory institutional logics. Journal of Professions and Organisation, 3(1), 1738.

Broadbent, J., Dietrich, M. \& Roberts, J. (1997). The End of Professions? in Broadbent, J., Dietrich, M., and Roberts, J. (eds), The End of the Professions? The Restructuring of Professional Work, London: Routledge.

Bourgeault, I.L., Benoit, C. \& Hirschkorn, K. (2009). Introduction: Comparative Perspectives on Professional Group: Current Issues and Critical Debates. Current Sociology, 57(4), 475485.

Brock, D.M. \& Saks, M. (2016). Professions and organisations: A European perspective. European Management Journal, 34, 1-6.

Buch, A. \& Andersen, V. (2013). (De)stabilising Self-Identities in Professional Work. Nordic Journal of Working Life Studies, 3(3), 155-173.

Burgess, J., Connell, J, \& Winterton, J. (2013.) Vulnerable workers, precarious work and the role of trade unions and HRM. The International Journal of Human Resource Management 24(22), 4083-4093. 
Butcher, J.N. (2003). Assessing Pilots with 'the Wrong Stuff': A Call for Research on Emotional Health Factors in Commercial Aviators. International Journal of Selection and Assessment, 10(1-2), 168-184.

Charmaz, K. (2006). Constructing grounded theory: A practical guide through qualitative research. London: Sage Publications.

Civil Aviation Authority (2007). Aircrew Fatigue: A Review of Research Undertaken on Behalf of the UK Civil Aviation Authority. CAA Paper 2005/04.

Cahill, A. (2015). Ryanair contract practice ‘a threat to safety’. Irish Examiner 8/5/15.

Retrieved from www.irishexaminer.com/ireland/ryanair-contract-practice-a-threat-to-safety.

Civil Aviation Authority (2015). EASA flight time limitations. Retrieved from www.caa.co.uk/Commercial-industry/Airlines/Flight-time-limitations/EASA-Flight-Time-

Limitations/.

Civil Aviation Authority (2015). Airline Data Annual Reports. Retrieved from www.caa.co.uk/Data-and-analysis/UK-aviation-market/Airlines/Datasets/UK-Airline-data/Airlinedata-annual-reports-2015/

Creswell, J.W. (2014). $4^{\text {th }}$ edition. Research Design: Qualitative, Quantitative and Mixed Methods Approaches. LA, USA: Sage.

Davies, R. (2017). Ryanair pilots form unofficial union in battle with Michael O’Leary. The Guardian, October 2nd. Retrieved from www.theguardian.com/business/2017/oct/02/ryanairpilots-union-michael-o-leary

Department of Transport (2013). UK Aviation Forecasts. Retrieved from www.gov.uk/government/

Edemariam, A. (2015). Sky high: who'd be an airline pilot today? The Guardian, October $24^{\text {th }}$. Retrieved from www.theguardian.com European Aviation Safety Agency (2017). Retrieved from www.easa.europe.eu 
European Cockpit Association (2017). Retrieved from www.eurocockpit.be/campaign/stopapy-fly

Evans, L. (2008). Professionalism, professionality and the development of education professionals. British Journal of Educational Studies, 56(1), 20-28.

Evetts, J. (2011). A New Professionalism? Challenges and Opportunities. Current Sociology, 59(4), 406-422.

Ferguson, D. (2013). What are the best paid jobs in Britain? The Guardian 18 December. Retrieved from www.theguardian.com/money/2013/dec/18/what-are-the-best-paid-jobs-uk$\underline{2013}$.

Fraher, A.L. (2016). The vulnerability of quasi-professional experts: A study of the changing character of US airline pilots’ work. Economic and Industrial Democracy, 1-23.

Fraher, A.L. \& Gabriel, Y. (2014). Dreaming of Flying When Grounded: Occupational Identity and Occupational Fantasies of Furloughed Airline Pilots. Journal of Management Studies, 51(6), 926-951.

Fraher, A.L. \& Gabriel, Y. (2016). Meeting and Resisting the Corporate Body Snatchers: The US Piloting Profession in Times of Downsizing and Restructuring. Journal for Critical Organisation Inquiry, 14(1), 35-51.

Friedson, E. (1994). Professionalism reborn: Theory, prophecy and policy, Oxford: Polity Press.

Friedson, E. (2001). Professionalism, the Third Logic. Chicago:Wiley.

Fuchs, C. (2014). Digital Labour and Karl Marx. Taylor Francis: Abingdon, UK.

Gendron, Y. \& Suddaby, R. (2004). Professional Insecurity and the Erosion of Accountancy’s Jurisdictional Boundaries. Canadian Accountancy Perspectives, 3(1), 85-115. 
Gittell, J.H., Cameron, K., Sandy, L. \& Victor, R. (2006). Relationships, Layoffs, and Organisational Resilience: Airline Industry Responses to September 11. The Journal of Applied Science, 42(3), 300-329.

Gioia, D.A., Corley, K.G. \& Hamilton, A.L. (2012). Seeking Qualitative Rigor in Inductive Research: Notes on the Gioia Methodology. Organisational Research Methods, 16(1), 15-31. Goos, M., Manning, A. \& Salamon, A. (2009) Job Polarisation in Europe. American Economic Review: Articles and Proceedings, 99(2), 58-63.

Harvey, G. \& Turnbull, P. (2010). On the Go: walking the high road at a low cost airline. The International Journal of Human Resource Management, 21(2), 230-241.

Haug, M.R. (1975). The Deprofessionalisation of Everyone? Sociological Focus, 8(3), 197213.

Hewison, K. (2016). Precarious Work. Chapter 23 in Sociology of Work and Employment, Edgell, S., Gottfried, H. \& Granter, E. (editors), London: Sage Publications,428-443. Hopkins, B. (2015). Occupational health and safety of temporary and agency workers. Economic and Industrial Democracy, April 29.

Jackson, C.A. \& Earl, L. (2006) Prevalence of fatigue among commercial pilots. Occupational Medicine, 56(4), 263-268.

Johnston, C.S., Maggiori, C. \& Rossier J. (2016.) Professional Trajectories, Individual Characteristics, and Staying Satisfied and Healthy. Journal of Career Development, 43(1), 81-98.

Jorens, Y., Gillis, D., Valke, L. \& De Coninck, J. (2015). Atypical Forms of Employment in the Aviation Sector. European Social Dialogue, European Commission. Kalleberg, A. (2012). Job Quality and Precarious Work: Clarifications, Controversies, and Challenges. Work and Occupations, 39(4), 427-448. 
Kretsos, L. \& Livanos, I. (2016. The extent and determinants of precarious employment in Europe. International Journal of Manpower, 37(1), 25-43.

Lewchuk, W., Clarke, M. \& de Wolff, A. (2008) Working without commitments: precarious employment and health. Work, Employment and Society, 22(3), 387-406.

Office of National Statistics Annual Survey of Hours and Earnings (2013). Retrieved from http://www.ons.gov.uk/ons/rel/ashe/annual-survey-of-hours-and-earnings/2013.

Markle, D.T., West, R.E., \& Rich, P.J. (2011) Beyond Transcription: Technology, Change and Refinement of Method. Qualitative Social Research, 12(3). Retrieved from: http//www. qualitative-research.net/index.php/fqs/article/view/1564/3248.

Mosoetsa, S., Stillerman, J. \& Tilly, C. (2016). Precarious Labor, South and North: An Introduction. International Labor and Working Class History, 89, 5-19.

Muzio, D., Brock D.M. \& Suddaby, R. (2013). Professions and Institutional Change: Towards an Institutionalist Sociology of the Professions. Journal of Management Studies, 50(5), 699-721.

Oxenbridge, S., Wallace, J., White, L., Tiernan, S. \& Lansbury, R. (2010). A comparative analysis of restructuring employment relationships in Qantas and Aer Lingus: different routes, similar destinations. The International Journal of Human Resource Management, 21(2), 180-196.

Pate, J. \& Beaumont, P. (2006) The European Low Cost Airline Industry: The Interplay of Business Strategy and Human Resources. European Management Journal, 24(6), 322-329. Patton, J. (2015). Human Resource Management in the Aviation Industry. The Journal of Global Business Management, 11(1), 1-12.

Patton, M.Q. (2015). $4^{\text {th }}$ edition. Qualitative Research \& Evaluation Methods: Integrating Theory and Practice. LA, USA: Sage. 
Putnam, L.L., Myers, K. \& Gaillard, B.M. (2014). Examining the tensions in workplace flexibility and exploring options for new directions. Human Relations. 67(4), doi: /abs/10.1177/0018726713495704.

Prosser, T. (2015). Dualisation or liberalisation? Investigating precarious work in eight European countries. Work, Employment and Society, first published on 5 November, 1-17. Riwo-Abudho, M., Njanja, L.W. \& Ochieng, I. (2013) Key Success Factors in Airlines: Overcoming the Challenges. European Journal of Business and Management, 5(30), 84-88. Rosekind, M.R. (2010). Effects of Commuting on Pilot Fatigue: An NTSB Perspective. National Transportation Safety Board. Retrieved from www.ntsb.gov.

Sarker, M.A.R., Hossan, C.G. \& Saman, L. (2012). Sustainability and growth of Low Cost Airlines: An Industry Analysis in Global Perspective. American Journal of Business and Management, 1(3), 162-171.

Standing, G. (2011). The Precariat: The New Dangerous Class, London and New York: Bloomsbury Academic.

Taylor, P. \& Moore, S. (2015). Cabin crew collectivism: labour process and the roots of mobilization. Work, employment and society, 29(1), 79-98.

The Guild of Air Pilots and Air Navigators 1929-2004 (2004). $75^{\text {th }}$ Anniversary publication. Retrieved from www.airpilots.org

Thompson, P. \& McHugh, D. (2002). Work Organisations: A Critical Introduction, $3^{\text {rd }}$ edition, Basingstoke, UK: Palgrave.

Thomson, K. \& Jones, J. (2016). Precarious Professionals: (in)Secure Identities and Moral Agency in Neocolonial Context. Journal of Business Ethics. doi:10.1077/s10551-016-3218-3. Tovey, A. (2014). What to be a pilot? Count the cost first. The Telegraph, 12 April. Retrieved from www.telegraph.co.uk/finance/jobs/10761957/Want-to-be-a-pilot-Count-the-cost-first. 
Work Disorganisation, and Consequences for Occupational Health: A Review of Recent Research. International Journal of Health Studies, 31(2), 335-414.

Vono de Vilhena, D., Kosyakova, Y., Kilpi-Jakonen, E. \& McMullin, P. (2016). Does adult education contribute to securing non-precarious employment? A cross-cultural comparison. Work, Employment and Society, 30(1), 97-117.

Watling Neal, J., Neal, Z.P., Van Dyke, E., and Kornbluh, M. (2015). Expediting the analysis of qualitative data in evaluation: a procedure for the rapid identification of themes from audio recordings. American Journal of Evaluation, 36(1), 118-132.

Webb, J. (2004). Organisations, Self-identities and the New Economy. Sociology, 38(4), 719738.

Worrall, L., Mather, K. \& Cooper, C. (2016). The changing nature of professional and managerial work. Chapter in Wilkinson, A., Hislop, D. \& Coupland, C. (editors) Perspectives on contemporary professional work. Cheltenham: Edward Elgar Publishing. Wright, O. (2013). You though Ryanair's attendants had it bad? Wait until you hear about their pilots. The Independent 17 May. The Independent 17 May http://www.independent.co.uk/news/uk/home-news/you-thought-ryanairs-attendants-had-itbad-wait-til-you-hear-about-their-pilots. 